\title{
Novel ZnO:Ag nanocomposites induce significant oxidative stress in human fibroblast malignant melanoma (Ht144) cells
}

\author{
Syeda Arooj ${ }^{1,2}$, Samina Nazir ${ }^{1}$, Akhtar Nadhman ${ }^{3}$, Nafees Ahmad ${ }^{4}$, \\ Bakhtiar Muhammad ${ }^{2}$, Ishaq Ahmad ${ }^{5}$, Kehkashan Mazhar ${ }^{4}$ and Rashda Abbasi ${ }^{*}$
}

\author{
Full Research Paper \\ Address: \\ ${ }^{1}$ Nanosciences and Catalysis Division, National Centre for Physics, \\ Quaid-i-Azam University campus, Islamabad, Pakistan, ${ }^{2}$ Department \\ of Chemistry, University of Hazara, Mansehra, KPK, Pakistan, \\ ${ }^{3}$ Department of Biotechnology, Faculty of Biological Science, \\ Quaid-i-Azam University, Islamabad, Pakistan, ${ }^{4}$ Institute of \\ Biomedical and Genetic Engineering, G-9/1, Islamabad, Pakistan and \\ ${ }^{5}$ Accelerator Lab, National Centre for Physics, Quaid-i-Azam \\ University campus, Islamabad, Pakistan \\ Email: \\ Rashda Abbasi ${ }^{*}$ - r.abbasi@daad-alumni.de \\ * Corresponding author \\ Keywords: \\ cancer therapy; cytotoxicity; photo-oxidation; ZnO:Ag nanocomposites

\begin{abstract}
Beilstein J. Nanotechnol. 2015, 6, 570-582.
\end{abstract} \\ doi:10.3762/bjnano.6.59 \\ Received: 15 September 2014 \\ Accepted: 28 January 2015 \\ Published: 26 February 2015 \\ Associate Editor: T. P. Davis \\ (C) 2015 Arooj et al; licensee Beilstein-Institut. \\ License and terms: see end of document.
}

Open Access

\begin{abstract}
The use of photoactive nanoparticles (NPs) such as zinc oxide $(\mathrm{ZnO})$ and its nanocomposites has become a promising anticancer strategy. However, $\mathrm{ZnO}$ has a low photocatalytic decomposition rate and the incorporation of metal ions such as silver (Ag) improves their activity. Here different formulations of $\mathrm{ZnO}: \mathrm{Ag}(1,3,5,10,20$ and $30 \% \mathrm{Ag})$ were synthesized by a simple co-precipitation method and characterized by powder X-ray diffraction, scanning electron microscopy, Rutherford back scattering and diffuse reflectance spectroscopy for their structure, morphology, composition and optical band gap. The NPs were investigated with regard to their different photocatalytic cytotoxic effects in human malignant melanoma (HT144) and normal (HCEC) cells. The $\mathrm{ZnO}: \mathrm{Ag}$ nanocomposites killed cancer cells more efficiently than normal cells under daylight exposure. Nanocomposites having higher Ag content $(10,20$ and $30 \%)$ were more toxic compared to low Ag content (1,3 and 5\%). For HT144, under daylight exposure, the $\mathrm{IC}_{50}$ values were $\mathrm{ZnO}: \mathrm{Ag}(10 \%): 23.37 \mu \mathrm{g} / \mathrm{mL}, \mathrm{ZnO}: \mathrm{Ag}(20 \%): 19.95 \mu \mathrm{g} / \mathrm{mL}$, and $\mathrm{ZnO}: \mathrm{Ag}(30 \%): 15.78 \mu \mathrm{g} / \mathrm{mL}$. $\mathrm{ZnO}: \mathrm{Ag}(30 \%)$ was toxic to $\mathrm{HT} 144\left(\mathrm{IC}_{50}: 23.34 \mu \mathrm{g} / \mathrm{mL}\right)$ in dark as well. The three nanocomposites were further analyzed with regard to their ability to generate reactive oxygen species (ROS) and induce lipid peroxidation. The particles led to an increase in levels of ROS at cytotoxic concentrations, but only HT144 showed strongly induced MDA level. Finally, NPs were investigated for the ROS species they generated in vitro. A highly significant increase of ${ }^{1} \mathrm{O}_{2}$ in the samples exposed to daylight was observed. Hydroxyl radical species, $\mathrm{HO}^{\circ}$, were also generated to a lesser extent. Thus, the incorporation of Ag into ZnO NPs significantly improves their photo-oxidation capabilities. $\mathrm{ZnO}: \mathrm{Ag}$ nanocomposites could provide a new therapeutic option to selectively target cancer cells.
\end{abstract}




\section{Introduction}

Zinc oxide $(\mathrm{ZnO})$ nanoparticles (NPs) exhibit an excellent photo-oxidation activity [1] and are considered as potential photoactivated NPs suitable for clinical applications [2,3]. Photoactive NPs provide an attractive, non-invasive alternate treatment option for cancer [4,5]. It involves the administration of photosensitizers followed by the illumination of canceraffected areas with light of an appropriate wavelength, and thus exciting the photosensitizer to produce reactive oxygen species (ROS) such as singlet oxygen $\left({ }^{1} \mathrm{O}_{2}\right)$ and hydroxyl radicals (HO') $[6,7]$. Photo-oxidation holds promises for the targeted treatment and controlled elimination of cancer cells [8]. ZnO NPs have also shown photo-oxidative anticancer activity against different cancer cell lines in vitro $[1,9,10]$.

ZnO NPs have a vast range of biological applications because they are biocompatible, considered to be safe [11] with a survival lifetime of a few hours in the body, and they can be dissociated and absorbed quickly. ZnO NPs exhibit antibacterial properties $[12,13]$, are used in the cosmetics industry $[14,15]$, and are used as nanoscale biosensors [11] and as drug carriers $[16,17]$. These NPs are being increasingly recognized due to their differential activity against tumor cells while being non-toxic to normal cells [18-22]. The preferential target of $\mathrm{ZnO}$ NPs are rapidly growing cells whereas quiescent cells are not as sensitive $[14,17,23]$ and in combination with photo-oxidation a targeted elimination of the cancer cells can be achieved.

The photonic efficiency of ZnO NPs is however considered unsatisfactory, as their photocatalytic decomposition process is slow and needs to be improved [24]. Therefore, it is interesting to enhance their photocatalytic ability and anticancer activity by forming nanocomposites with other materials, including metal ions such as silver $(\mathrm{Ag})$ or iron (Fe) ions [25]. The $\mathrm{ZnO}: \mathrm{Ag}$ nanocomposites exhibit an improved photocatalytic activity [26,27] and photostability [28] compared to the ZnO NPs. Nanoscale $\mathrm{Ag}^{2+}$ itself exhibits antimicrobial and anticancer activity [29], therefore it might be a very interesting and useful addition to the ZnO NPs as it not only enhances the photocatalytic activity of the particles but might also improve their anticancer effects.

In this study, we investigated $\mathrm{ZnO}$ and different $\mathrm{ZnO}: \mathrm{Ag}$ (1-30\%) nanocomposites with regard to their cytotoxic effect in human malignant melanoma cells (HT144) and normal cells (HCEC). Combined with the MTT and sulforhodamine B (SRB) assay the cytotoxicity in vitro and the differential effect of different $\mathrm{Ag}$ contents in the $\mathrm{ZnO}$ nanoparticles affecting cell proliferation was analyzed. The photo-oxidation-mediated cytotoxicity of different NPs was investigated by irradiating the samples with daylight or keeping them in the dark. The nanocomposites were studied regarding their ability to generate ROS and lipid peroxidation by chemical trapping method (DPBF; 1,3-diphenylisobenzofuran) and the thiobarbituric acidreactive species (TBARs) assay, respectively. Generation of various ROS species was studied by using scavengers such as mannitol, sodium azide $\left(\mathrm{NaN}_{3}\right)$ and dimethyl sulfoxide (DMSO). To the best of our knowledge, the preparation and characterization of $\mathrm{ZnO}: \mathrm{Ag}$ nanocomposites with varying amounts of Ag incorporated and the study of their anticancer activity has not been reported, yet.

\section{Results \\ Characterization of nanocomposites}

The scanning electron microscopy (SEM) image (Figure 1) shows that all the synthesized composites had nanoscale dimensions, with sizes ranging from 30 to $40 \mathrm{~nm}$.

The X-ray diffraction analysis (XRD) patterns of the $\mathrm{ZnO}: \mathrm{Ag}$ nanocomposites (Figure 2) contains $\mathrm{ZnO}$ phases corresponding to the wurzite structure at $2 \theta$ values of $31.8,34.4,36.3,47.6$, $56.6,62.9,66.4,67.9$ and $69.1^{\circ}$ in accordance with the zincite stick pattern COD 9004180 . No other peak for the cubic phases of $\mathrm{ZnO}$ or any other $\mathrm{ZnO}$ structures such as $\mathrm{ZnO}_{2}$ or $\mathrm{Zn}(\mathrm{OH})_{4}$ was seen. The Ag present in the $\mathrm{ZnO}: \mathrm{Ag}$ composite nanoparticles appeared as cubic phases of pure silver crystals at $2 \theta$ values of $38.2,44.4,64.5^{\circ}$ in accordance with reference stick pattern COD 9011607. The appearance of Ag as a separate crystal indicates that $\mathrm{Ag}$ is not incorporated into the wurzite structure of $\mathrm{ZnO}$ but preserved its crystalline form. The co-growth of $\mathrm{ZnO}$ wurzite and Ag cubic structures took place through the adopted in situ doping procedure. The decrease in $\mathrm{ZnO}$ peak heights with the increase in $\mathrm{Ag}$ amount indicated that $\mathrm{ZnO}$ crystal structure deteriorated to smaller crystallites as silver started growing as a separate phase along the $\mathrm{ZnO}$ crystals.

Rutherford backscattering spectrometry (RBS) analysis (Figure 3a and Table 1) shows that our samples contain the correct elemental compositions regarding $\mathrm{Zn}, \mathrm{O}$ and $\mathrm{Ag}$ and confirm the presence of $\mathrm{Zn}: \mathrm{O}: \mathrm{Ag}$ in 1:1:0.01, 1:1:0.03, 1:1:0.05, 1:1:0.1, 1:1:0.2 and 1:1:0.3 ratios in $\mathrm{ZnO}: \mathrm{Ag}(1 \%), \mathrm{ZnO}: \mathrm{Ag}$ (3\%), $\mathrm{ZnO}: \mathrm{Ag}$ (5\%), $\mathrm{ZnO}: \mathrm{Ag}(10 \%), \mathrm{ZnO}: \mathrm{Ag}(20 \%)$ and $\mathrm{ZnO}: \mathrm{Ag}(30 \%)$ percent, respectively. Ag was found in fractions of 1.3 2.9, 4.6, 9.7, 20.6 and 29.3\% in $\mathrm{ZnO}: \mathrm{Ag}(1 \%), \mathrm{ZnO}: \mathrm{Ag}$ (3\%), $\mathrm{ZnO}: \mathrm{Ag}$ (5\%), $\mathrm{ZnO}: \mathrm{Ag}(10 \%), \mathrm{ZnO}: \mathrm{Ag}(20 \%)$ and $\mathrm{ZnO}: \mathrm{Ag}(30 \%)$ samples, respectively.

The band-gap studies of the nanocomposites carried out through diffused reflectance spectra (DRS) analysis show a characteristic absorption edge near $390 \mathrm{~nm}$ (Figure 3b). The non-doped 

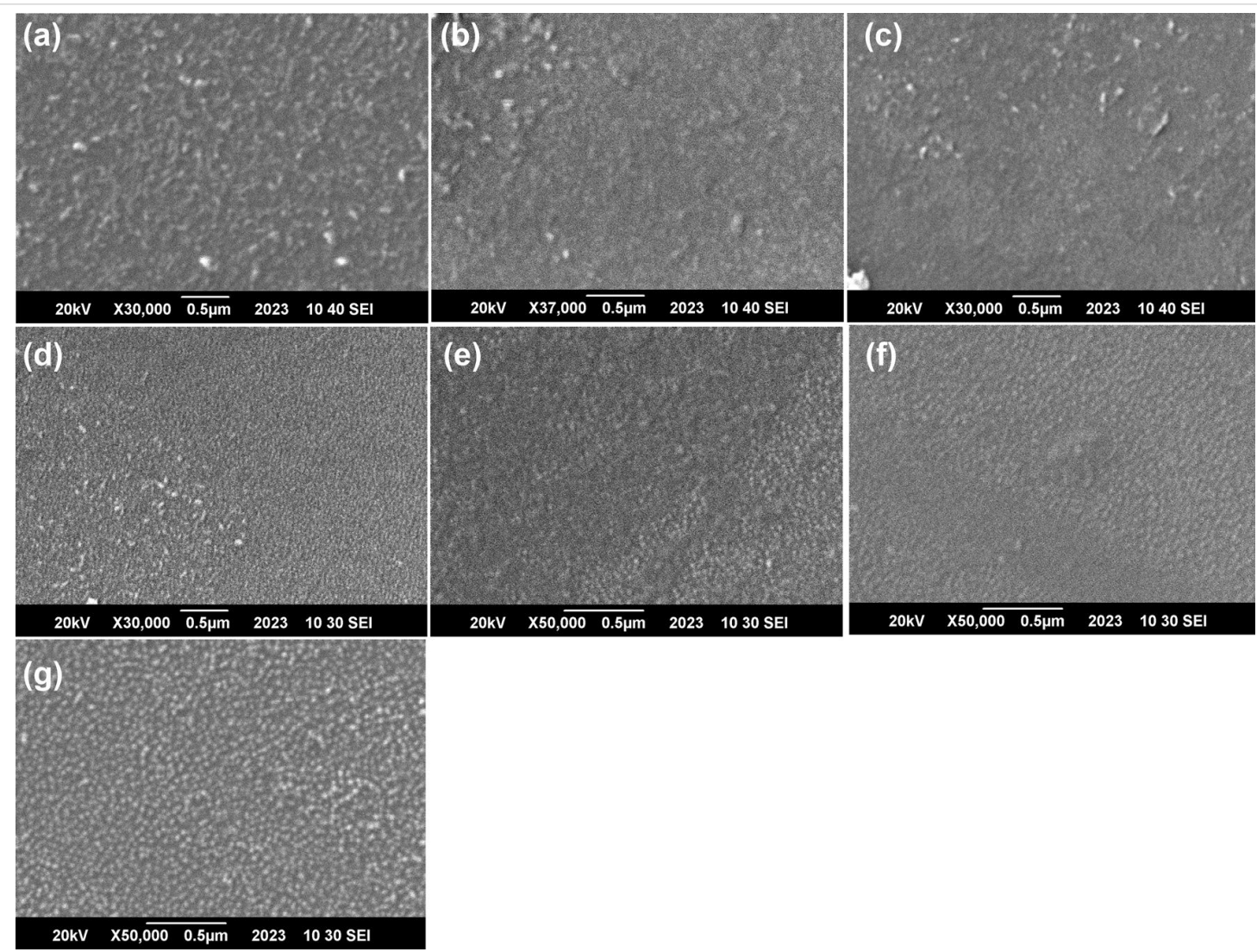

Figure 1: SEM images of the different zinc oxide nanoparticles. (a) ZnO, (b) ZnO:Ag (1\%), (c) ZnO:Ag (3\%), (d) ZnO:Ag (5\%), (e) ZnO:Ag (10\%), (f) ZnO:Ag (20\%), and (g) ZnO:Ag (30\%).

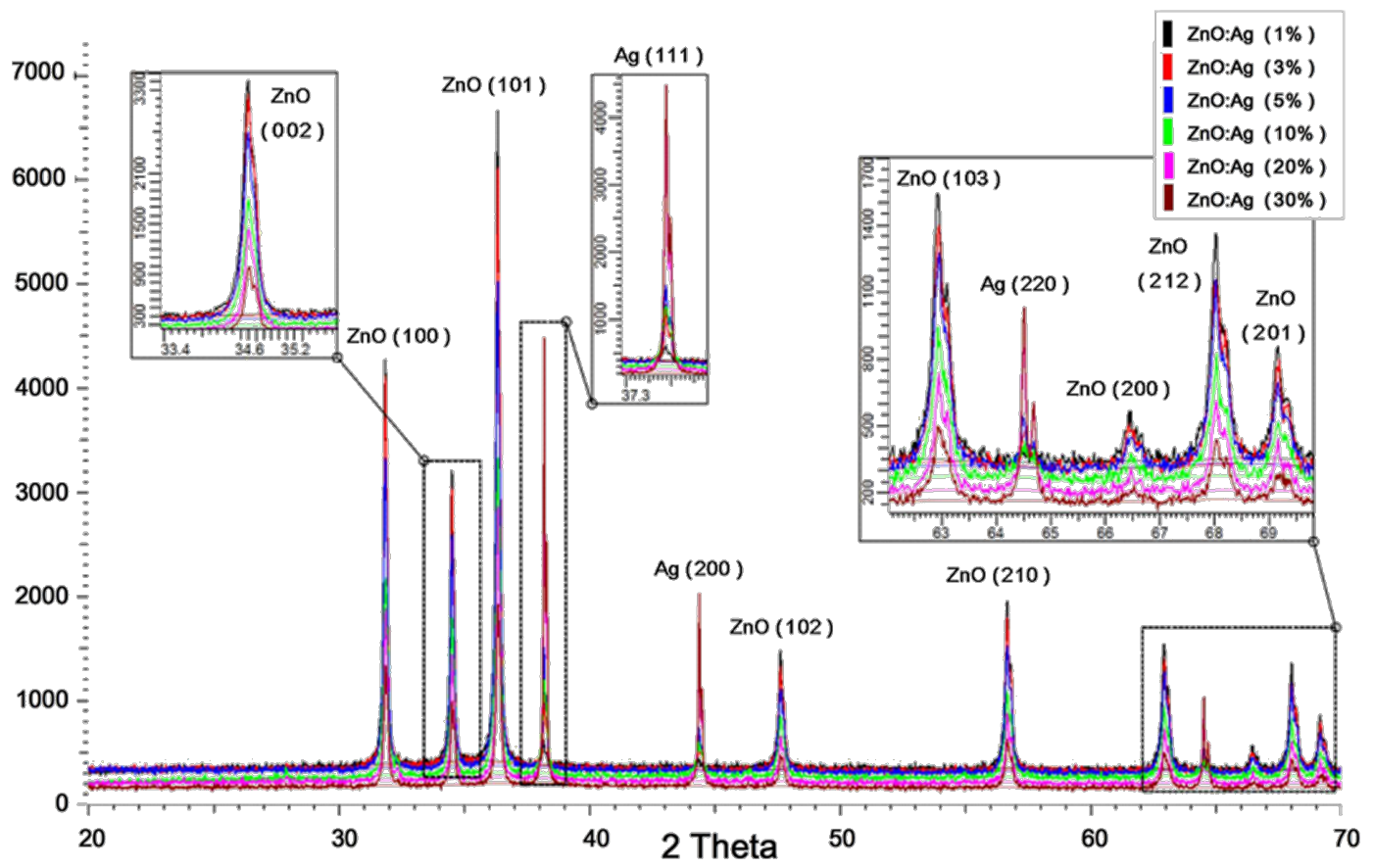

Figure 2: $\mathrm{XRD}$ patterns of different types of $\mathrm{ZnO}$ :Ag nanoparticles show the $\mathrm{ZnO}$ wurzite hexagonal crystalline structure and presence of the cubic crystalline form of Ag. Inset: magnified part of the spectrum showing the decrease in height of the $\mathrm{ZnO}$ peaks with an increase in the appearance of the Ag phase. 


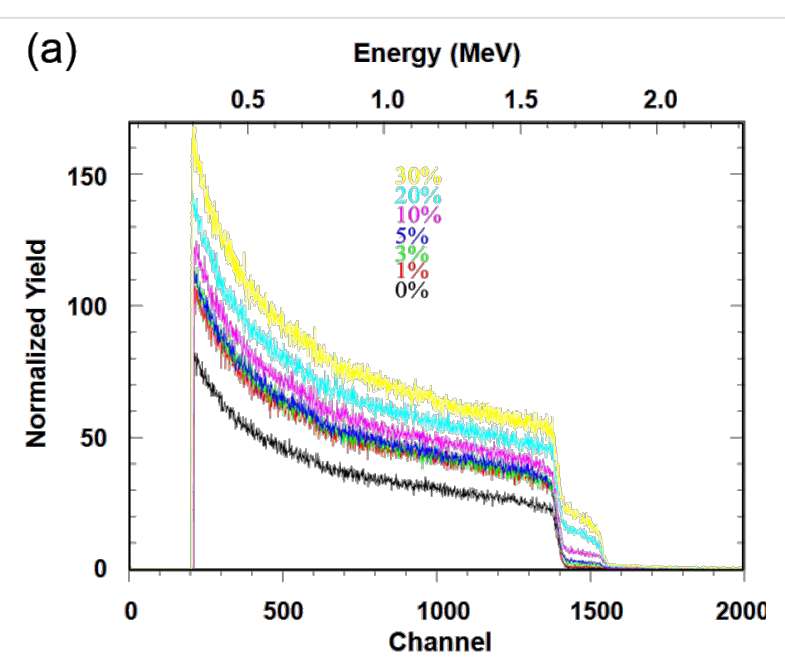

(b)

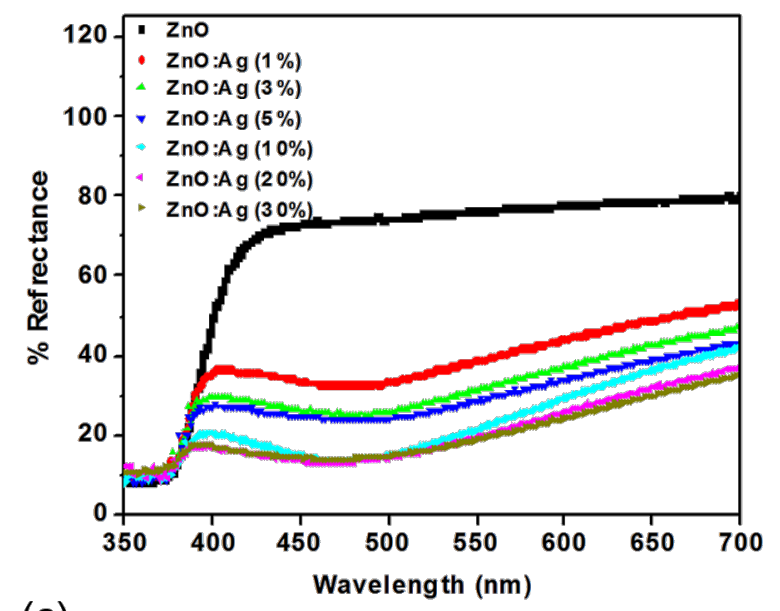

(c)

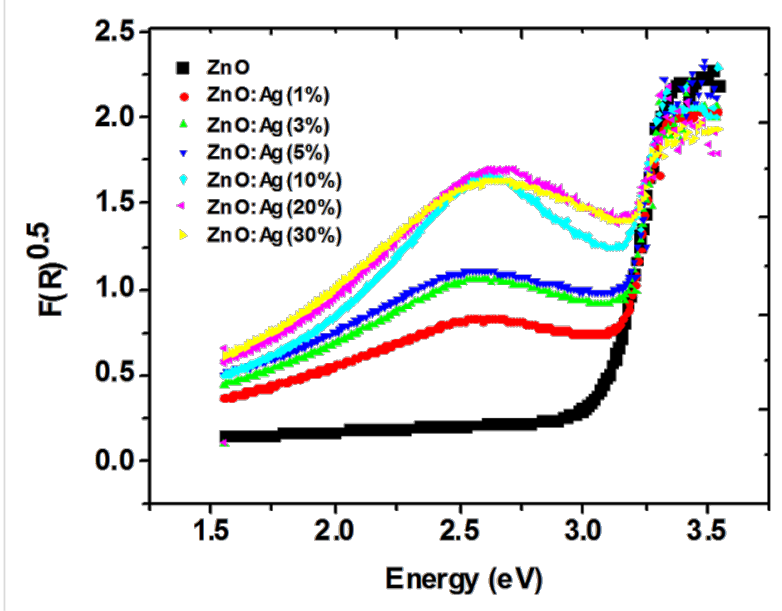

Figure 3: Characterization of the different $\mathrm{ZnO}$ and $\mathrm{ZnO}$ :Ag nanocomposites. (a) RBS analysis; atomic composition graph is showing the relative amounts of $\mathrm{Zn}, \mathrm{O}$ and silver, (b) diffused reflectance spectra, (c) band gap energies of the different nanocomposites.

$\mathrm{ZnO}$ showed a high reflectance, while Ag-doped $\mathrm{ZnO}$ showed low reflectance and more absorbance in the visible region. Moreover, the intensity of reflectance decreased with the
Table 1: RBS analysis of $\mathrm{ZnO}: \mathrm{Ag}$ nanoparticles indicating the relative quantities of $\mathrm{Zn}, \mathrm{O}$ and $\mathrm{Ag}$ in the prepared samples.

\begin{tabular}{llll} 
& Zn & O & Ag \\
\hline ZnO & 1 & $0.9898 \pm 0.0016$ & 0 \\
ZnO:Ag (1\%) & 1 & $0.9706 \pm 0.0028$ & $0.0132 \pm 0.0004$ \\
ZnO:Ag (3\%) & 1 & $1.0139 \pm 0.0110$ & $0.0287 \pm 0.0006$ \\
ZnO:Ag (5\%) & 1 & $1.0163 \pm 0.0001$ & $0.0459 \pm 0.0027$ \\
ZnO:Ag (10\%) & 1 & $1.0028 \pm 0.0121$ & $0.0973 \pm 0.0017$ \\
ZnO:Ag (20\%) & 1 & $1.0195 \pm 0.0212$ & $0.2059 \pm 0.0064$ \\
ZnO:Ag (30\%) & 1 & $0.9938 \pm 0.0116$ & $0.2932 \pm 0.0002$
\end{tabular}

increase of Ag contents. The band gap energies of the nondoped $\mathrm{ZnO}$ and $\mathrm{Ag}$-doped $\mathrm{ZnO}$ were calculated by plotting the square of the Kubelka-Munk function $[F(R)]^{1 / 2}$ versus the energy in eV (electron volts) [30].

A band-gap decrease was observed in all the Ag-doped $\mathrm{ZnO}$ to the varying extents depending upon the doped $\mathrm{Ag}(1,3,5,10$, 20 , and $30 \% \mathrm{Ag}$ ). Silver resulted in a band structure in visible region in all the $\mathrm{ZnO}: \mathrm{Ag}$ nanocomposites (Figure $3 \mathrm{c}$ ).

\section{Screening of NPs for cytotoxicity}

The $\mathrm{ZnO}$ :Ag nanocomposites were screened for cytotoxicity against two cell lines, HT144 (human malignant melanoma) and HCEC (normal cell line). The cells were treated with different dilutions of the NPs ranging from 0 to $125 \mu \mathrm{g} / \mathrm{mL}$ for $24 \mathrm{~h}$ and then submitted to the SRB assay. NP treatments were categorized as having 'no effect' when the measured viability was above $50 \%$, having a 'moderate effect' when the viability was between 50 and $25 \%$, and having a 'strong effect' when a viability below $25 \%$ was observed. By using these categories, as shown in Figure 4, ZnO NPs had 'no differential effect' on both normal as well as cancer cells at 25 and $50 \mu \mathrm{g} / \mathrm{mL}$, however at $125 \mu \mathrm{g} / \mathrm{mL}$, a moderate effect of the NPs was observed on HT144 cells.

For $\mathrm{ZnO}: \mathrm{Ag}$ nanocomposites, at $25 \mu \mathrm{g} / \mathrm{mL}$ either 'no effect' was observed or the effects were similar in both the normal as well as the cancer cells and were therefore considered as not differentially affecting the cancer cells. At $50 \mu \mathrm{g} / \mathrm{mL}$, a differential effect of the NPs was observed, which increased with the increase in Ag content in the NPs. ZnO:Ag (10\%), ZnO:Ag $(20 \%)$ and $\mathrm{ZnO}: \mathrm{Ag}(30 \%)$ had a strong differential activity against the cancer cells as compared to the normal cells with a percent viability of $32.69 \pm 4.81 \mu \mathrm{g} / \mathrm{mL}, 15.01 \pm 5.85 \mu \mathrm{g} / \mathrm{mL}$ and $27.18 \pm 9.81 \mu \mathrm{g} / \mathrm{mL}$, respectively. $\mathrm{ZnO}: \mathrm{Ag}(5 \%)$ had a slight but significant effect $(p \leq 0.0001)$ on the cancer cell line when compared to the normal cells. Whereas $\mathrm{ZnO}, \mathrm{ZnO}: \mathrm{Ag}$ (1\%), $\mathrm{ZnO}: \mathrm{Ag}(3 \%)$, had no effect on the two cell lines. At 


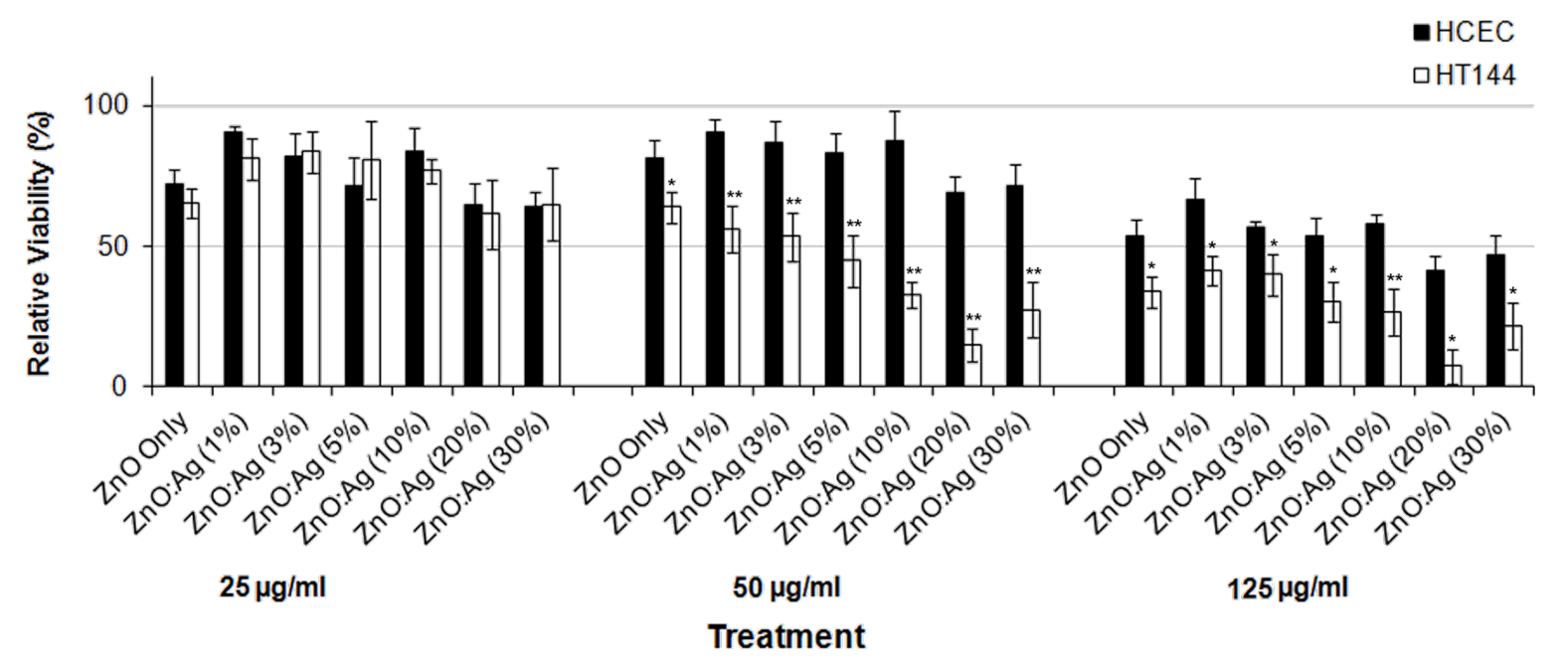

Figure 4: Effect of $\mathrm{ZnO}$ and $\mathrm{ZnO}$ :Ag nanocomposites on the viability of HT144 (skin cancer) and HCEC (normal) cells using SRB assay. Exponentially growing cultures were treated with different concentrations of the nanoparticles $(25,50$, and $125 \mu \mathrm{g} / \mathrm{mL})$ for $24 \mathrm{~h}$. Percent viabilities (mean $\pm \mathrm{SD}$ ) were calculated relative to NTC. ${ }^{*} p<0.001,{ }^{* *} p<0.0001$ (two tailed t-test) when compared to HCEC.

$125 \mu \mathrm{g} / \mathrm{mL}$, all the NPs were significantly toxic $(p \leq 0.01)$ to HT144 as well as HECE cells when compared to the untreated cells (NTC). Hence, this concentration was considered as 'too toxic' for the cultures.

Depending on strongest differential effects three NPs i.e., $\mathrm{ZnO}: \mathrm{Ag}(10 \%), \mathrm{ZnO}: \mathrm{Ag}(20 \%)$ and $\mathrm{ZnO}: \mathrm{Ag}(30 \%)$ were selected for further analyses and $\mathrm{ZnO} \mathrm{NPs}$ were included as Ag-free NP control.

\section{Selected NPs show strong and differential photo-oxidation mediated cytotoxicity in cancer versus normal cells}

HT144 and HCEC cultures were exposed to increasing concentrations of the selected NPs, either exposed to daylight or kept in dark and further incubated for $24 \mathrm{~h}$. Percent viabilities were calculated relative to $\mathrm{NTC}$ and $\mathrm{IC}_{50}$ values were calculated from the drug response curves (Figure 5). $\mathrm{ZnO}$ did not kill more than $50 \%\left(\mathrm{IC}_{50} \geq 100 \mu \mathrm{g} / \mathrm{mL}\right)$ of the HT144 and HCEC cells at the concentrations tested. $\mathrm{ZnO}: \mathrm{Ag}(10 \%)$ and $\mathrm{ZnO}: \mathrm{Ag}(20 \%)$ did not kill more than $50 \%$ of the HCEC cells $\left(\mathrm{IC}_{50} \geq\right.$ $100 \mu \mathrm{g} / \mathrm{mL}$ ) at the concentrations tested under both light and dark conditions. For HT144 these NPs did not kill more than $50 \%$ of the cells at the concentrations tested under dark conditions. However, samples that were exposed to light showed a marked sensitivity to the nanocomposites with an $\mathrm{IC}_{50}$ of 23.37 and $19.95 \mu \mathrm{g} / \mathrm{mL}$, respectively. ZnO:Ag (30\%) treated HT144 cells were highly sensitive to the NPs under both light and dark conditions, with an $\mathrm{IC}_{50}$ of 15.78 and $23.34 \mu \mathrm{g} / \mathrm{mL}$, respectively. Complete cell death was observed at 50,75 and $100 \mu \mathrm{g} / \mathrm{mL}$ under light exposure. However, it did not kill more than $50 \%$ of the HCEC cells $\left(\mathrm{IC}_{50} \geq 100 \mu \mathrm{g} / \mathrm{mL}\right)$ at the concentrations tested under both light and dark conditions.

The results indicate that $\mathrm{ZnO}: \mathrm{Ag}$ nanocomposites have a higher photo-oxidative effect when compared with $\mathrm{ZnO}$ particles. In addition, the selected NPs show strong and differential cytotoxicity in cancer versus normal cells.

\section{Detection of singlet oxygen by chemical trap- ping (DPBF)}

The release of ${ }^{1} \mathrm{O}_{2}$ into aqueous solution was estimated indirectly by using the DPBF assay. DPBF reacts irreversibly with ${ }^{1} \mathrm{O}_{2}$ causing a decrease in its absorption intensity at $410 \mathrm{~nm}$. The different NPs $(100 \mu \mathrm{g} / \mathrm{mL})$ were mixed in DPBF solution and upon irradiation absorption was measured over a period of time. The natural logarithm values of absorption of DPBF were calculated to show an increase in the amount of ${ }^{1} \mathrm{O}_{2}$.

As shown in Figure 6, the samples with only DPBF (quantum yield $\Phi_{\Delta}=0.043 \pm 0.02$ ) had a slight increase in the ${ }^{1} \mathrm{O}_{2}$ production, which represents the baseline ${ }^{1} \mathrm{O}_{2}$ release by DPBF itself whereas methylene blue $\left(\mathrm{MB} ; \Phi_{\Delta}=0.49 \pm 0.02\right)$ caused a significant increase in the ${ }^{1} \mathrm{O}_{2}$ levels. The $\mathrm{ZnO}$ NPs $\left(\Phi_{\Delta}=0.41 \pm 0.04\right)$ also had a significant increase in the ${ }^{1} \mathrm{O}_{2}$ levels. However, its level was slightly lower than that of MB. Both $\mathrm{ZnO}: \mathrm{Ag}(10 \%)$ and $\mathrm{ZnO}: \mathrm{Ag}(20 \%)$ nanocomposites $\left(\Phi_{\Delta}=0.58 \pm 0.02\right.$ and $\Phi_{\Delta}=0.57 \pm 0.05$, respectively) had a similar induction of ${ }^{1} \mathrm{O}_{2}$ that was significantly increased compared to the $\mathrm{ZnO} N P s$. For $\mathrm{Zn}: \mathrm{Ag}(30 \%)\left(\Phi_{\Delta}=0.75 \pm 0.02\right)$ 
(a)

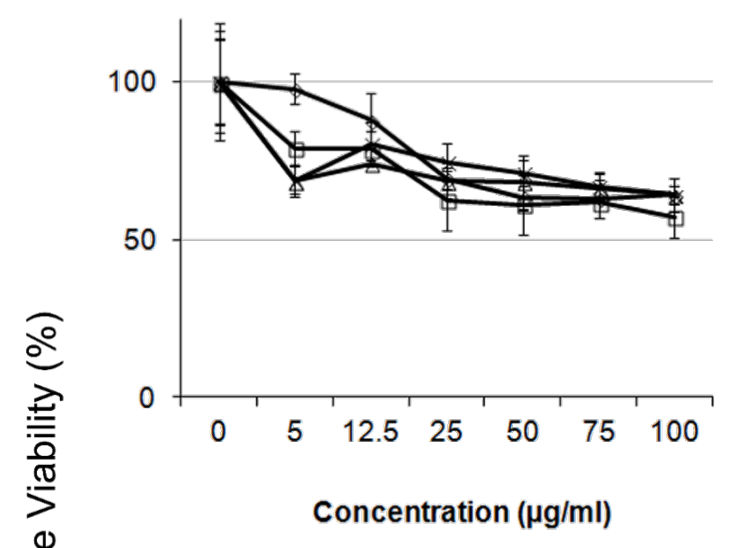

(c)

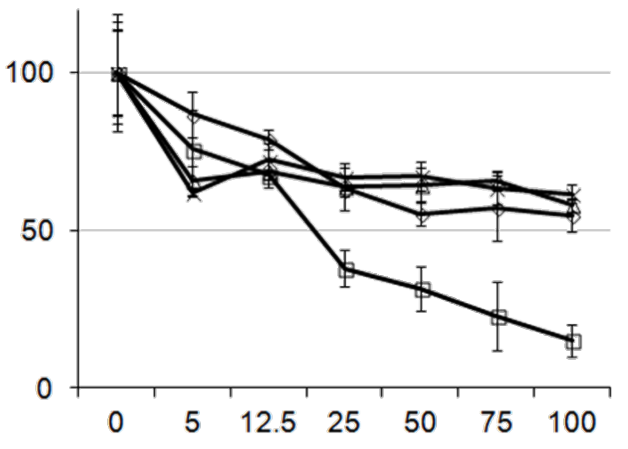

(b)

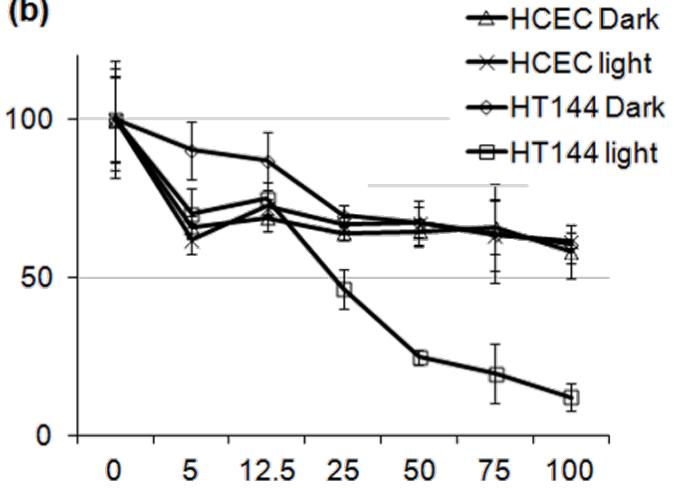

Concentration $(\mu \mathrm{g} / \mathrm{ml})$

(d)

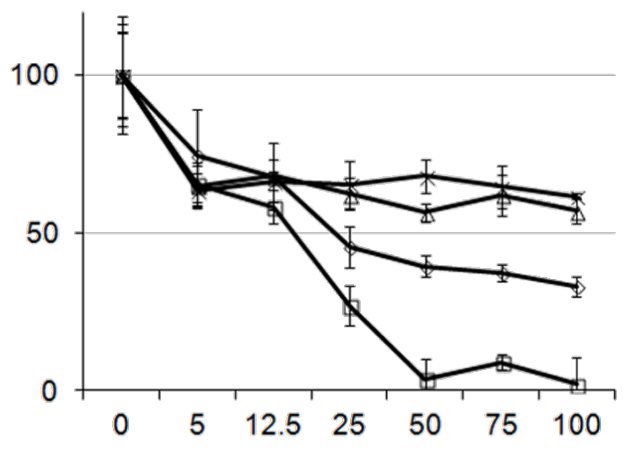

Concentration $(\mu \mathrm{g} / \mathrm{ml})$

Concentration $(\mu \mathrm{g} / \mathrm{ml})$

Figure 5: Comparison of the effect of $\mathrm{ZnO}$ and $\mathrm{ZnO}$ :Ag nanocomposites on mitochondrial function (MTT reduction) in HT144 (skin cancer) and HCEC (normal) cells. Exponentially growing cultures were treated with different concentrations $(5,12.5,25,50,75,100 \mu \mathrm{g} / \mathrm{mL}$ ) of the nanoparticles and in order to analyze the photo-oxidative effect of nanoparticles, the cultures were exposed to daylight or kept in dark at $37^{\circ} \mathrm{C}$ for 15 min and further incubated for $24 \mathrm{~h}$. MTT reduction (mean \pm SD) was measured. NTC were included as control. (a) ZnO, (b) ZnO:Ag (10\%), (c) ZnO:Ag (20\%), and (d) $\mathrm{ZnO}: \mathrm{Ag}(30 \%)$. The experiment was performed twice with triplicates of each sample.
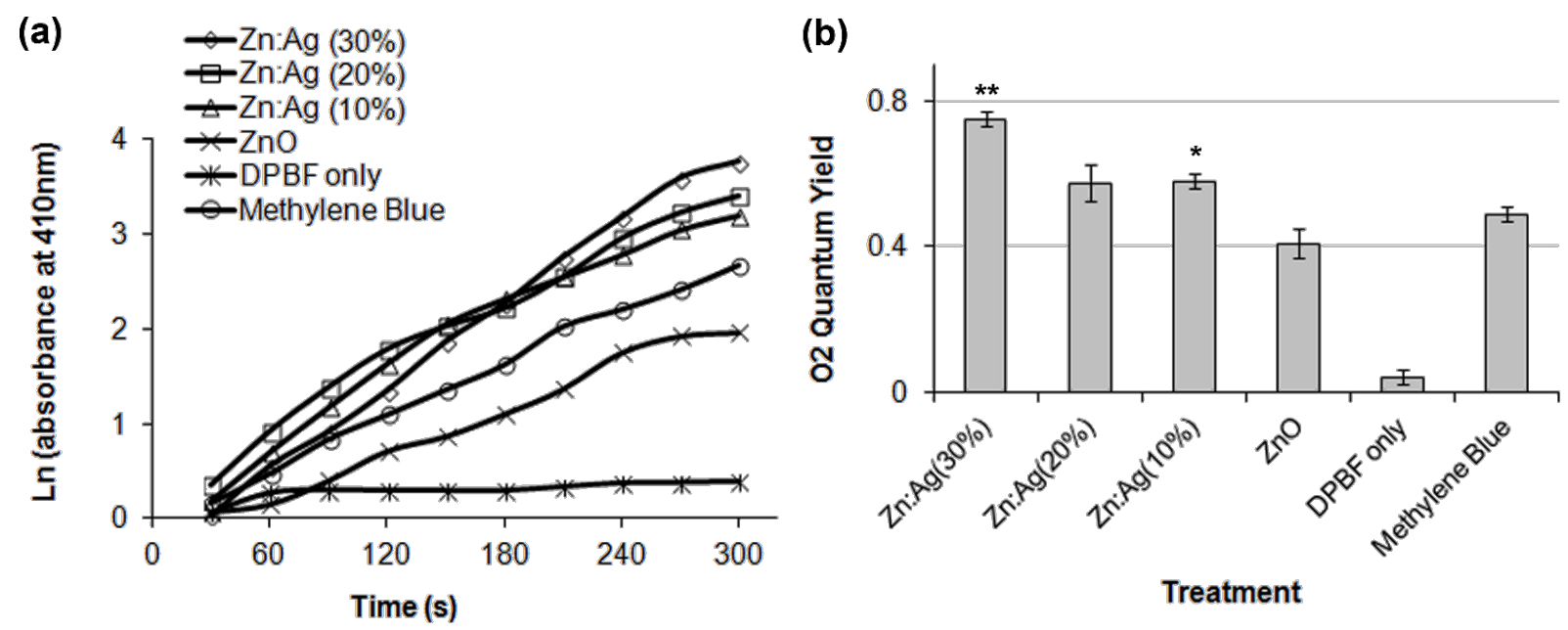

Figure 6: Consumptions of the singlet oxygen indicator DPBF mixed with $\mathrm{ZnO}$ and $\mathrm{ZnO}: \mathrm{Ag}$ nanocomposites under the exposure to light and recorded every $30 \mathrm{~s}$. (a) Time course of the natural log of absorption spectrum of DPBF at $410 \mathrm{~nm}$. (b) Quantum yield (mean \pm SD) of singlet oxygen. ${ }^{*} p<0.01$ ${ }^{* *} p<0.0001$ (two tailed t-test) in comparison to MB. 
a much stronger induction $(p<0.0001)$ in ${ }^{1} \mathrm{O}_{2}$ production was observed and the level was about double compared to that of $\mathrm{ZnO}$ NPs. These results indicate that $\mathrm{ZnO}$ NPs induce the production of ${ }^{1} \mathrm{O}_{2}$ and this production is significantly improved in $\mathrm{ZnO}: \mathrm{Ag}$ nanocomposites in aqueous solution.

\section{Induction of oxidative stress: lipid peroxida- tion (LPO)}

To investigate the induction of oxidative stress by the nanocomposites, cells were cultured at various concentrations $(5,12.5$ and $25 \mu \mathrm{g} / \mathrm{mL}$ ) of the NPs for $24 \mathrm{~h}$, followed by the evaluation of malondialdehyde (MDA) levels by TBARs assay. As controls NTC and non-cellular background samples were also included.

For HT144 cells, as shown in Figure 7, the average MDA level of NTC was $8.05 \pm 3.73$ and $4.16 \pm 3.23$ in light and dark exposed samples, respectively. $\mathrm{ZnO}: \mathrm{Ag}$ (10\%), $\mathrm{ZnO}: \mathrm{Ag}(20 \%)$ and $\mathrm{ZnO}: \mathrm{Ag}(30 \%)$ treatment resulted in an at least 6-fold increase in TBARs concentration compared with $\mathrm{ZnO}$, under light exposure at the concentrations $(5,12.5$ and $25 \mu \mathrm{g} / \mathrm{mL})$ tested. A highly significant $(p \leq 0.0001)$ induction of MDA was obtained in HT144 under light exposure as compared to the samples kept under dark. For $\mathrm{ZnO}$ treated samples no significant increase in MDA levels was observed. For HCEC cells, the average MDA level of NTC was $7.24 \pm 3.43$ and $2.58 \pm 2.54$ in light and dark exposed samples, respectively. For nanoparticles treated samples no significant increase in MDA levels was observed either under light or dark condition.

\section{ROS species in $\mathrm{ZnO}$ :Ag nanocomposites induced oxidative stress in HT144 cells}

ROS are a family of oxygen-centered species including ${ }^{1} \mathrm{O}_{2}$, $\mathrm{HO}^{\bullet}$ and $\mathrm{H}_{2} \mathrm{O}_{2}$. To characterize the possible ROS induced by the nanocomposites, a set of ROS scavengers, namely mannitol, $\mathrm{NaN}_{3}$ and DMSO were used to study their inhibitory effect on NPs induced ROS formation (Figure 7). The HO` scavenger mannitol improved cell viability by 10 to $30 \%$ in NP treated, light exposed samples, corroborating the involvement of $\mathrm{HO}^{\circ}$. The ${ }^{1} \mathrm{O}_{2}$ scavenger $\mathrm{NaN}_{3}$ had a much stronger effect on cell viability and improved it by 30 to $50 \%$ in NP treated, light exposed samples, indicating ${ }^{1} \mathrm{O}_{2}$ as major ROS species. DMSO addition had only a slight effect on rescuing the cells. These results demonstrate the involvement of ${ }^{1} \mathrm{O}_{2}$ and $\mathrm{HO}^{\bullet}$ in NPs induced ROS (Figure 8).

\section{Discussion}

In the current study, $\mathrm{ZnO}: \mathrm{Ag}$ nanocomposites with varying amounts of $\operatorname{Ag}(1,3,5,10,20$, and $30 \%)$ were synthesized. As a control $\mathrm{ZnO}$ only NPs were also included. The nanocomposites were hexagonal in structure containing the metallic silver on surface, with a size range of $30-40 \mathrm{~nm}$. The RBS analysis of $\mathrm{ZnO}: \mathrm{Ag}$ nanoparticles indicated the purity of the prepared samples with the atomic percentages of $\mathrm{Zn}, \mathrm{O}$ and $\mathrm{Ag}$ according to the expectations. Zinc and oxygen are present in correct stoichiometric amounts indicating the presence of pure $\mathrm{ZnO}$ and excluding any possible presence of the $\mathrm{ZnO}_{2}$ structure. The minor variation in oxygen amount is, however, due to oxygen vacancies created by the Fermi gas we used in our annealing

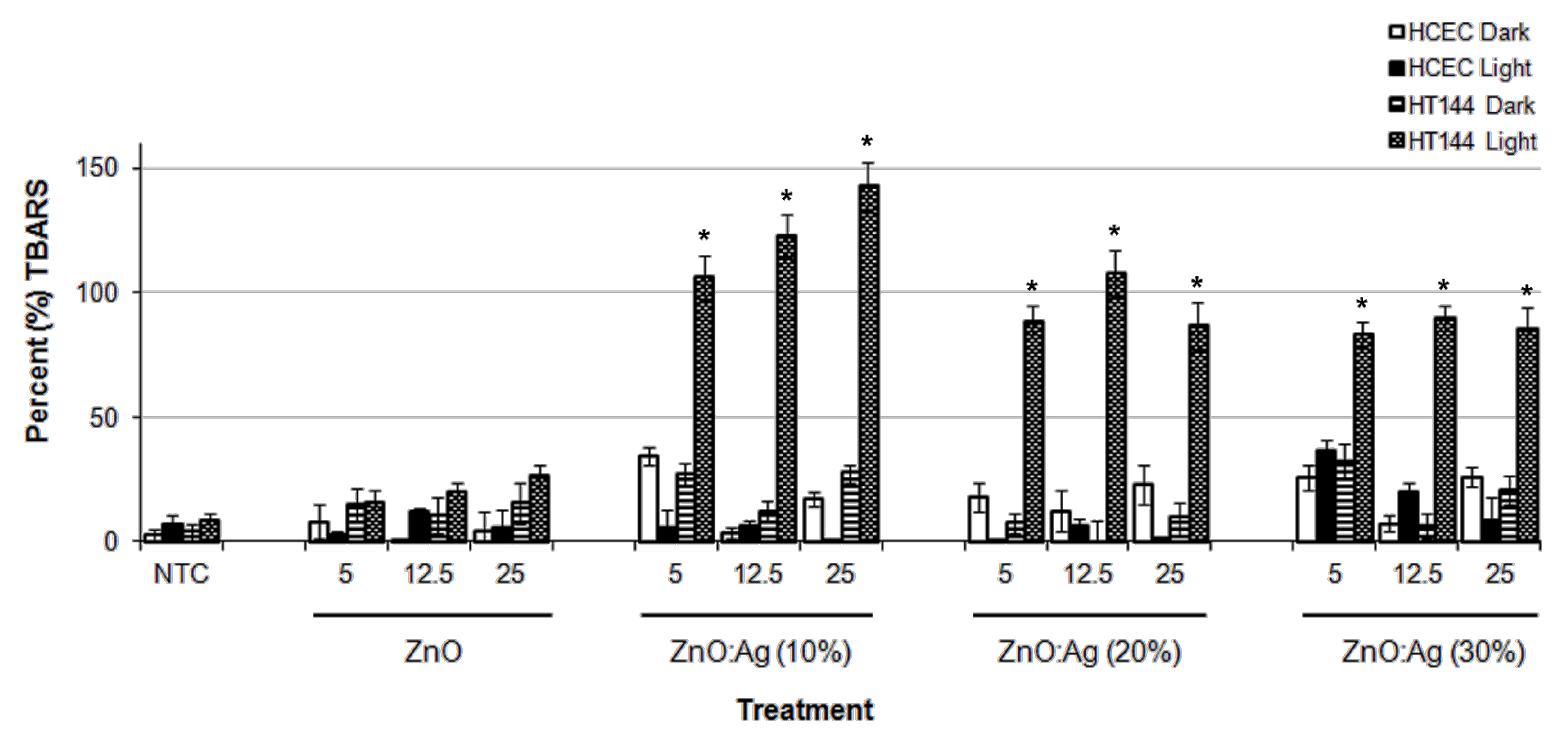

Figure 7: TBA assay results for nanoparticle exposure. Data is expressed as percent (\%) TBARS (mean \pm SD) relative to the NTC sample. ${ }^{*} p<0.0001$ (two tailed t-test) when compared to HCEC dark, HCEC light and HT144 dark. 
(a)

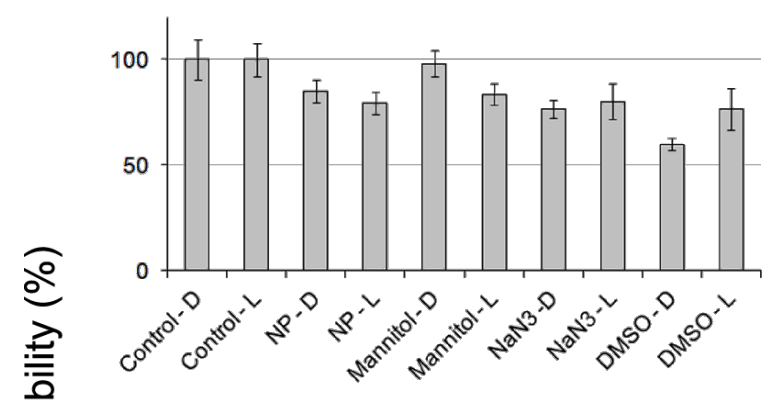

(c)

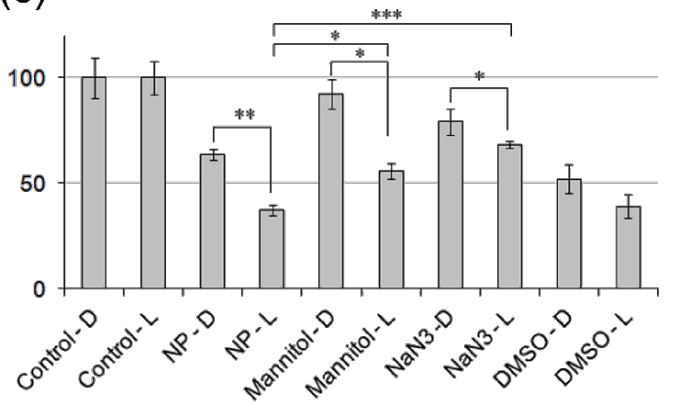

(b)

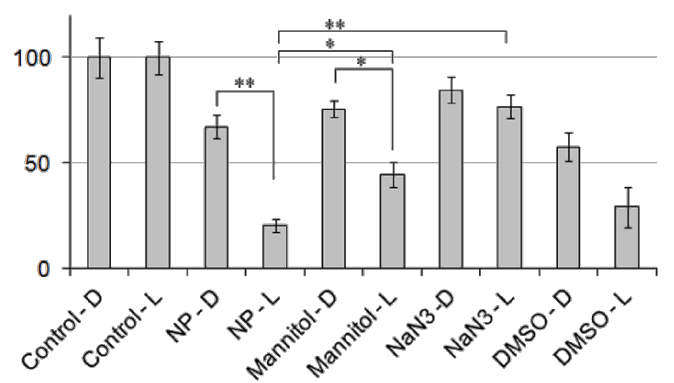

(d)

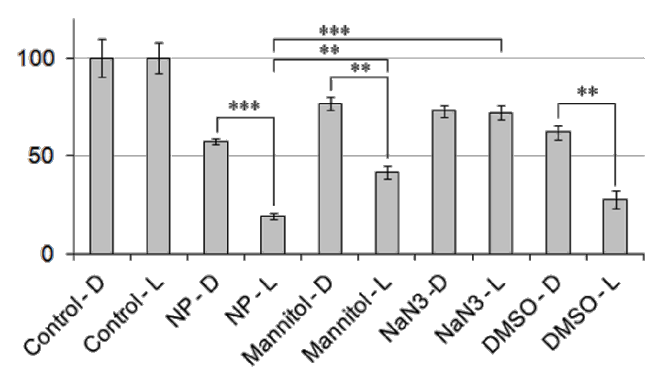

Treatment

Figure 8: Effect of ROS scavengers mannitol, $\mathrm{NaN}_{3}$ and DMSO on the photo-oxidative activity of $\mathrm{ZnO}$ and $\mathrm{ZnO}: \mathrm{Ag}$ nanocomposites as measured by MTT assay in HT144 (skin cancer) cells. Viability (mean \pm SD) was calculated relative to the NTC samples. (a) ZnO, (b) ZnO:Ag (10\%), (c) ZnO:Ag $(20 \%)$, and (d) ZnO:Ag (30\%). ${ }^{*} p<0.01,{ }^{* *} p<0.001,{ }^{* * *} p<0.0001$ (two tailed t-test).

procedure. These oxygen vacancies gradually obtained some atmospheric oxygen when samples were stored under normal atmospheric conditions. The nanocomposites were screened for cytotoxicity against two human cell lines, HT144 (malignant melanoma) and HCEC (normal cells). $\mathrm{ZnO}: \mathrm{Ag}$ nanocomposites showed a clear photo-oxidation-mediated cytotoxic activity against the cancer cells, nanocomposites having a higher content of $\mathrm{Ag}$ (10 to $30 \%$ ) being more toxic compared to low $\mathrm{Ag}(1$ to $5 \%)$ content. ZnO NPs had no differential effect on both normal as well as cancer cells under light or dark conditions. The $\mathrm{IC}_{50}$ values indicate that $\mathrm{ZnO}: \mathrm{Ag}$ nanocomposites have a higher cytotoxic effect when compared with ZnO NPs. In addition the selected NPs show strong and differential cytotoxicity in cancer versus normal cells. A recent study by Ismail et al. [31] reported $\mathrm{ZnO}: \mathrm{Ag} \mathrm{NPs}\left(\mathrm{IC}_{50}\right.$ values 45.10$)$ as cytotoxic to HepG2 cells under UV illumination; however, their effect was similar to the effect of $\mathrm{ZnO}-\mathrm{NPs}$ ( $\mathrm{IC}_{50}$ values 42.60) under the same conditions. The authors however did not mention the percentage of Ag content in these NPs. Whereas our $\mathrm{ZnO}: \mathrm{Ag}$ nanocomposites with a higher Ag content (10 to $30 \%$ ) had a stronger and differential effect in comparison to the ZnO NPs on HT144 cells under daylight condition. The reason we have stronger effect might be due to a difference in the light source used, the percentage of Ag content or the cellular model used. Sharma et al. [32] reported zinc oxide nanoparticles with different formulations $(0.1,0.2,0.3$ and $0.4 \%)$ of $\mathrm{Ag}$ (size range: $23-59 \mathrm{~nm}$ ) for their antibacterial activity and Shah et al. [33] reported that $\mathrm{ZnO}$ nanorods with 3\% Ag content (size: $12 \mathrm{~nm}$ ) were toxic to different bacterial strains. Talari et al. [34] reported that increase in $\mathrm{Ag}$ content in the $\mathrm{ZnO}$ :Ag nanocomposites improved the antimicrobial activity of these particles.

The addition of Ag content in ZnO NPs causes a positional shift in XRD pattern, reduction in size of the NPs and increase in the photocatalytic activity [26,34]. It is, however, not well-understood how these NPs exactly work in the exposed cells. $\mathrm{ZnO}$ NPs were reported to cause toxicity by generating ROS [35], causing DNA damage, oxidative stress [36], an increase in caspase-3 activity as well as p47phox NADPH (nicotinamide adenine dinucleotide phosphate)-oxidase-dependent superoxide generation [37] leading to apoptosis [21,23,38]. We therefore determine that a significantly higher amount of ${ }^{1} \mathrm{O}_{2}$ was being released in the aqueous solution by $\mathrm{ZnO}: \mathrm{Ag}(10-30 \%)$ nanocomposites, compared to the $\mathrm{ZnO}$ NPs under light exposure. We further investigated the induction of oxidative stress by the nanocomposites and observed a dose dependent increase 
in intracellular lipid peroxidation of HT144 cells only under light exposure compared to the $\mathrm{ZnO}$ NPs, whereas normal cells did not show such an increase. Furthermore, the study of different ROS species generated by the nanocomposites in HT144 and HCEC cells exhibited a highly significant increase in ${ }^{1} \mathrm{O}_{2}$ in light exposed samples followed by $\mathrm{HO}^{\circ}$ to a lesser extent. Ismail et al. [31] also reported the production of ROS, oxidative stress and up-regulation of the antioxidant defense system as a possible mechanism for the enhanced cytotoxicity by $\mathrm{ZnO}$ :Ag NPs. These findings show that the incorporation of $\mathrm{Ag}$ in the nanocomposites substantially enhances the photooxidative effect and anticancer activity of the NPs. The presence of Ag significantly improves the activity of $\mathrm{ZnO}$ nanoparticles in visible light range thus avoiding the use of UV or infrared light.

Our findings suggest that the major mechanism by which $\mathrm{ZnO}: \mathrm{Ag}$ nanocomposites mediate cell death is generation of ROS and induction of oxidative stress. ROS are involved in the activation of enzymes and transcription factors and in growth, differentiation and apoptosis [39]. The localized photo-oxidation of treated tissues affects only the area exposed to light leading to targeted tumor regression and disruption of blood supply [40]. However others have reported that ZnO NPs derived toxicity was due to dissolution of the particles and release of free metal ions leading to cell death [41,42]. It is possible that the cytotoxic effects are a result of a combination of both of these events. However, detailed investigation of the actual mode of action needs to be done.

\section{Conclusion}

Taken together, ROS-induced oxidative damage appears to be the underlying mechanism for the anticancer activity of $\mathrm{ZnO}: \mathrm{Ag}$ nanocomposites. These nanocomposites were selectively toxic to cancer cells exposed to light and at concentrations much lower than required for normal cells and quite effective compared to $\mathrm{ZnO} \mathrm{NP}$. We were able to show that the effect of $\mathrm{ZnO}$ NPs was improved by the formation of $\mathrm{ZnO}: \mathrm{Ag}$ nanocomposites thereby improving their cell killing ability. Daylightphotodynamic therapy can provide a basis for targeted cancer treatment. However, further studies are required to evaluate the potential cytotoxicity, biocompatibility and biosafety of such particles in vitro as well as in vivo.

\section{Experimental Reagents}

Acetic acid, DMSO, ethylenediaminetetraacetic acid disodium salt dihydrate $\left(\mathrm{Na}_{2} \mathrm{EDTA} \cdot 2 \mathrm{H}_{2} \mathrm{O}\right), \mathrm{FeSO}_{4}$, L-glutamine, hydrochloric acid $(\mathrm{HCl})$, mannitol, penicillin- $\mathrm{G}$, polyethylene glycol (PEG), pyruvic acid, silver nitrate, $\mathrm{NaN}_{3}$, sodium chloride, sodium dodecyl sulfate (SDS), sodium hydroxide $(\mathrm{NaOH})$, sodium sarcosinate, streptomycin sulfate, sulforhodamine B (SRB), 1,1,3,3-tetramethoxypropane, MTT, thiobarbituric acid (TBA), trichloroacetic acid (TCA), Triton X-100, trizma-Base, trypsin/EDTA (5\%), and zinc nitrate, were purchased from Sigma-Aldrich (USA). Dulbecco's Modified Eagle Medium (DMEM) and fetal bovine serum (FBS) were purchased from GibcoBRL, Gaithersburg, MD.

\section{Nanocomposite synthesis}

The nanocomposites $\mathrm{ZnO}: \mathrm{Ag}(1,3,5,10,20$ and 30\% Ag) were synthesized following a previously reported procedure with some modifications [29]. Briefly, zinc nitrate hexahydrate and the required amount of silver nitrate $(1,3,5,10,20$ and $30 \mathrm{~mol} \%$ ) were dissolved in $5 \% \mathrm{v} / \mathrm{v}$ Tween 80 to achieve $50 \mathrm{mM}$ concentration. The resulting substrate solution was titrated against $100 \mathrm{mM} \mathrm{NaOH}$ through a drop-wise addition to achieve $\mathrm{pH}$ 8.0. The resulting precipitates were heated at $80{ }^{\circ} \mathrm{C}$ for $2 \mathrm{~h}$, and filtrated through a cellulose membrane. The resulting material was thoroughly washed, dried, ground into fine powder and sieved. The nanocomposites were heated in a tube furnace under an argon (Ar) atmosphere (flow rate $30 \mathrm{sccm}$ ) with a temperature rise of $4{ }^{\circ} \mathrm{C} / \mathrm{min}$ and then kept at $100{ }^{\circ} \mathrm{C}$ for $4 \mathrm{~h}$. In order to get rid of excess oxygen in the composite material, samples were further treated under reducing atmosphere ( $5 \%$ hydrogen in Ar) for $6 \mathrm{~h}$ at $450{ }^{\circ} \mathrm{C}$ (flow rate $30 \mathrm{sccm}$ ). Afterwards, the nanoparticles (NPs) were coated with PEG to stabilize the surface in biological environment [43]. For PEG coating, $50 \mathrm{mg}$ of nanoparticles were kept stirring in a $10 \mathrm{~mL}$ PEG 6000 solution $(1 \mathrm{mg} / \mathrm{mL})$ for $2 \mathrm{~h}$. Nanoparticles were stored in PEG environment for an extended period of time till needed for the biological evaluation. Before performing assays, we dialyzed our $\mathrm{ZnO}: \mathrm{Ag}$ nanocomposite suspensions with Spectra Por 6 (mw cutoff 25000) Spectrum ${ }^{\circledR}$ dialysis membrane for $4 \mathrm{~h}$ against deionized water.

\section{Characterization of nanocomposite}

The nanocomposites were characterized by SEM, XRD, Rutherford back scattering, UV-vis spectroscopy and DRS analysis. The samples were gold-coated and SEM analyses were performed on a JOEL-SM6460 SEM machine. The XRD analysis of the nanocomposites was performed on Shimadzo $6000 \mathrm{X}$-ray spectrophotometer by using $\mathrm{Cu} \mathrm{K \alpha}(\lambda=1.54 \AA)$ radiation at $40 \mathrm{kV}$ and $30 \mathrm{~mA}$. The diffraction pattern was recorded in the range of $2 \theta=20-70^{\circ}$. Rutherford backscattering spectrometry (RBS) was carried out on a $5 \mathrm{MV}$ pelletron tandem accelerator with $\mathrm{He}^{++}$beam of energy $2.085 \mathrm{MeV}$ employing $26 \mathrm{nA}$ current and a solid state barrier detector. Detector resolution was set at $20 \mathrm{keV}$. Incident angle during analysis was kept at $0^{\circ}$ whereas the backscattering angle was $170^{\circ}$. The data was analyzed via XRUMP and SIMNRA. Optical properties of composites were studied on a Lambda 950 
UV-vis-NIR spectrometer. The diffused reflectance spectra were collected within a range from $900 \mathrm{~nm}$ to $2500 \mathrm{~nm}$ through an integrating sphere. Band gap energies of the nanocomposites were calculated by the Kubelka-Munk function $F(R)$ by using the following equation [30].

$$
F(R)=\left[F\left(R_{\infty}\right) h v\right]^{2}
$$

where $F(R)$ is the Kubelka-Munk function; $R$ represents the absolute value of reflectance.

\section{Cell lines and cell culture}

Human malignant melanoma (HT144, ATCC HTB-63) cells were cultured in RPMI-1640 supplemented with 10\% FBS, $2 \mathrm{mM}$ L-glutamine, $1 \mathrm{mM}$ Na-pyruvate, $100 \mathrm{U} / \mathrm{mL}$ penicillin, $100 \mu \mathrm{g} / \mathrm{mL}$ streptomycin at $37{ }^{\circ} \mathrm{C}$ in a humidified $5 \% \mathrm{CO}_{2}$ atmosphere. The immortalized human corneal epithelial cells (HCEC; RIKEN Bio Resource Center, Japan) were cultured in DMEM containing 10\% FBS, $2 \mathrm{mM}$ L-glutamine, $1 \mathrm{mM}$ Na-pyruvate, $100 \mathrm{U} / \mathrm{mL}$ penicillin/streptomycin at $5 \% \mathrm{CO}_{2}$ and $37{ }^{\circ} \mathrm{C}$ in humidified environment. Cells were harvested by trypsinization with $1 \mathrm{~mL} 0.5 \mathrm{mM}$ trypsin/EDTA for $1 \mathrm{~min}$ at room temperature.

\section{Screening for photo-oxidative effect of NPs}

The nanoparticle stock suspensions $(1 \mathrm{mg} / \mathrm{mL})$ were prepared in de-ionized water and dispersed by sonication on sonifier cell disrupter $(40 \mathrm{~W}, 25 \mathrm{kHz})$ for $30 \mathrm{~min}$ in a water bath. The nanoparticle serial dilutions were prepared as required by using the appropriate cell culture medium. To screen the photo-oxidation-mediated effects of the NPs, briefly, $1.5 \times 10^{5}$ cells $/ \mathrm{mL}$ were seeded in $25 \mathrm{~cm}^{2}$ flasks, 6-well plates or 96-well plates and allowed to grow over night. For the different treatments, two identical sets of samples were prepared for each cell line. One set was exposed to daylight at $37^{\circ} \mathrm{C}$ for $15 \mathrm{~min}$, while the second set was kept under dark at $37{ }^{\circ} \mathrm{C}$ for $15 \mathrm{~min}$. Cultures were further grown at $37{ }^{\circ} \mathrm{C}, 5 \% \mathrm{CO}_{2}$ for $24 \mathrm{~h}$. Each experiment included NTC, media only and NPs only samples. The experiments were conducted at least twice with triplicates each.

\section{Measurement of cytotoxicity}

Pre-seeded cells ( $>90 \%$ viability; $1.5 \times 10^{5}$ cells $/ \mathrm{mL}$ ) were incubated with different dilutions of the nanoparticles $(25,50$ and $125 \mu \mathrm{g} / \mathrm{mL}$ ) for $24 \mathrm{~h}$ and cytotoxicity was measured by the SRB assay as previously described by Skehan et al. [44]. Briefly, cultures were fixed by gently adding $50 \%$ pre-chilled TCA and incubated at $4{ }^{\circ} \mathrm{C}$ for $1 \mathrm{~h}$. The plates were rinsed with deionized water at least five times and air-dried. Samples were stained with $0.4 \% \mathrm{SRB}$ solution for about $30 \mathrm{~min}$ at room temperature, rinsed with $1 \%$ acetic acid to completely remove the unincorporated dye and air-dried. The incorporated dye was solubilized in
Tris (10 mM, pH 8.0) and absorbance was measured on microplate reader (AMP PLATOS R-496) at the wavelength of $565 \mathrm{~nm}$.

Percent (\%) viability was calculated relative to the NTC sample using the following formula:

Viability $(\%)=\frac{\operatorname{Abs}(565)_{\text {sample }}-\operatorname{Abs}(565)_{\mathrm{NP} \text { control }}}{\operatorname{Abs}(565)_{\mathrm{NTC}}-\operatorname{Abs}(565)_{\mathrm{blank}}} \times 100$

where $\operatorname{Abs}(565)_{\text {sample }}$ and $\mathrm{Abs}(565)_{\mathrm{NTC}}$ represent the optical density at $565 \mathrm{~nm}$ for the treated samples and untreated control samples, respectively. Abs(565) $)_{\mathrm{NP}}$ control and $\operatorname{Abs}(565)_{\text {blank }}$ represent the background optical density and was measured in NPs only and media only samples. HCEC cells were included as a normal control cell line.

\section{Mitochondrial function: cell survival and prolif- eration assay}

MTT assay was used to investigate mitochondrial function as described by Mosman [45] with some modifications. In brief, pre-seeded cells ( $>90 \%$ viability; $1.5 \times 10^{5}$ cells $/ \mathrm{mL}$ ) were incubated with different dilutions of the nanoparticles $(5,12.5$, 25, 50, 75 and $100 \mu \mathrm{g} / \mathrm{mL}$ ) for $24 \mathrm{~h}$. As controls, NTC and the non-cellular background samples, i.e., media only and NPs only samples containing MTT and acidified 10\% SDS solution were also included in the experiment. Afterwards MTT solution $(0.5 \mathrm{mg} / \mathrm{mL})$ was added and samples were incubated for 3 hours at $37{ }^{\circ} \mathrm{C}$. The resulting formazan product was dissolved by adding equal amount of acidified $10 \%$ SDS and further incubated overnight at $37^{\circ} \mathrm{C}$. Absorbance was measured at $565 \mathrm{~nm}$ by using a microplate reader (AMP PLATOS R-496). The noncellular background was subtracted from the respective samples and percent viability was measured relative to the NTC samples. Viability curves for the different nanoparticles were generated and their $\mathrm{IC}_{50}$ values were calculated. The $\mathrm{IC}_{50}$ value for the nanoparticles represents the concentration that inhibits $50 \%$ of cell growth. The experiments were performed twice with triplicates for each sample.

\section{Detection of singlet oxygen by chemical trap- ping}

1,3-Diphenylisobenzofuran (DPBF) was used to determine the release of singlet oxygen $\left({ }^{1} \mathrm{O}_{2}\right)$ into the solution by the nanoparticles as described previously $[30,43,46]$. The samples were prepared immediately before use. In a typical experiment, $2 \mathrm{~mL}$ of an ethanol solution containing $0.08 \mathrm{mM} \mathrm{DPBF}$ and $100 \mu \mathrm{g} / \mathrm{mL}$ of the nanoparticles or MB solution were taken in a quartz cuvette in the dark. DPBF-only samples were also included. The experiments were carried out by exposing the samples to daylight filtered through a shortpass infrared filter 
$(<550 \mathrm{~nm})$. The absorbance of the solution was measured at $410 \mathrm{~nm}$, every $30 \mathrm{~s}$ for $5 \mathrm{~min}$ with a NanoDrop 2000 (Thermo Fisher Scientific). The decrease of absorbance caused by photobleaching of DPBF was measured and corrected in all experiments. The natural logarithm values of absorption of DPBF were plotted against the irradiation time and fit by a first-order linear least-squares model to get the decay rate of the photosensitized process. The ${ }^{1} \mathrm{O}_{2}$ quantum yield of the nanoparticles in aqueous solution was calculated using $\mathrm{MB}$ as a standard by the following formula:

$$
\Phi_{\Delta}^{\mathrm{b}}=\frac{\Phi_{\Delta}^{\mathrm{a}}}{I^{\mathrm{a}}} I^{\mathrm{b}} .
$$

$\Phi_{\Delta}^{\mathrm{b}}$ is the ${ }^{1} \mathrm{O}_{2}$ quantum yield of the nanoparticles, $\Phi_{\Delta}^{\mathrm{a}}$ is the ${ }^{1} \mathrm{O}_{2}$ quantum yield of MB that was calculated by using Rose Bengal (RB) as a standard ( $\Phi_{\mathrm{RB}}=0.75$ in $\mathrm{H}_{2} \mathrm{O}$ [47]), $I^{\mathrm{b}}$ is the slope of the nanoparticles and represents the time for the decrease in absorption of DPBF in the presence of the nanoparticles and $I^{\mathrm{a}}$ is the slope of $\mathrm{MB}$ and represents the time for the decrease in absorption of DPBF in the presence of the MB.

\section{Induction of oxidative stress}

The extent of membrane lipid peroxidation (LPO) was estimated by measuring the formation of MDA by using the TBARs assay as described by Ohkawa et al. [48] with some modifications. MDA is one of the products of membrane LPO. Briefly, pre-seeded cultures ( $>90 \%$ viability; $1.5 \times 10^{5}$ cells $\left./ \mathrm{mL}\right)$ were exposed to different concentrations $(5$, 12.5 and $25 \mu \mathrm{g} / \mathrm{mL}$ ) of the nanoparticles for $24 \mathrm{~h}$. NTC and non-cellular background (media only and compounds only samples containing cell lysis buffer, 10\% SDS and TBA solution) were included in each experiment as controls. After the treatment, cells were washed and harvested in ice-cold phosphate buffer saline at $4{ }^{\circ} \mathrm{C}$. Cells were then lysed in cell lysis buffer $(2.5 \mathrm{M} \mathrm{NaCl}, 10 \mathrm{mM}$ Trizma-base at $\mathrm{pH}$ 10.0, $100 \mathrm{mM}$ $\mathrm{Na}_{2}$ EDTA, $1 \%$ sodium sarcosinate, $1 \%$ Triton $\mathrm{X}-100,10 \%$ DMSO) and centrifuged at $15000 \mathrm{~g}$ for $10 \mathrm{~min}$ at $4{ }^{\circ} \mathrm{C}$. The supernatant was collected and maintained on ice until it was further assayed. To the cell lysate $(0.1 \mathrm{~mL})$ an equal amount of $10 \%$ SDS was added and samples were incubated at room temperature for $5 \mathrm{~min}$. Then, $0.25 \mathrm{~mL}$ of TBA $(5.2 \mathrm{mg} / \mathrm{mL})$ was added to the mixture and incubated at $95{ }^{\circ} \mathrm{C}$ for $45 \mathrm{~min}$. After cooling to room temperature, absorbance of the mixture was measured at $532 \mathrm{~nm}$ by NanoDrop 2000 (Thermo Fisher Scientific). The non-cellular background was subtracted from the respective samples and percent TBARs were calculated relative to the NTC sample. The experiments were performed twice with triplicates for each sample.

To study the possible ROS produced, the NPs were characterized by using a set of chemical scavengers, i.e., $\mathrm{NaN}_{3}$, mannitol, and DMSO. $\mathrm{NaN}_{3}$, a scavenger of singlet oxygen $\left({ }^{1} \mathrm{O}_{2}\right)$, was used at a concentration of $0.1 \%$. Mannitol, a scavenger of hydroxyl radical $\left(\mathrm{HO}^{\circ}\right)$, was used at a concentration of $10 \mathrm{mM}$ (final $1 \mathrm{mM}$ ). DMSO, a scavenger of hydroxyl radical (HO'), was used at a concentration of $0.5 \%$. Cultures were treated with the scavengers for $1 \mathrm{~h}$ at $37{ }^{\circ} \mathrm{C}$ before exposure to the different concentrations $(5,12.5$ and $25 \mu \mathrm{g} / \mathrm{mL})$ of the NPs. Cells were further incubated for $24 \mathrm{~h}$ at $37{ }^{\circ} \mathrm{C}$ and $5 \% \mathrm{CO}_{2}$ and their viability was measured relative to the NTC by using MTT assay.

\section{Statistical analysis}

The results are presented as mean $\pm \mathrm{SD}$. ANOVA and two tailed t-test were used to investigate the differences between NTC, nanoparticles treated and solvent exposed samples. The photo-oxidative effect of the NPs was measured by comparing the samples exposed to the different light conditions. Obtained results were considered significant when $p<0.05$.

\section{Acknowledgements}

We wish to thank Noor Khan (Institute of Biomedical and Genetic Engineering, Islamabad) and Zahir Shah (Quaid-iAzam University, Islamabad) for their excellent technical/ research assistance. We thankfully acknowledge the kind support of Dr. Tajammul Hussain (Late; Nanosciences and Catalysis Division, National Centre for Physics, Islamabad), Dr. Syeda S. Naz (Nanosciences and Catalysis Division, National Centre for Physics, Islamabad) and Dr. Ashraf Gondal (King Fahad University of Petroleum and Minerals, KFUPM, SaudiArabia) for their help and guidance in starting this project. We are also thankful to Dr. Turab Ali Abbas (Experimental Physics Lab, National Centre for Physics, Islamabad) for providing some of the analysis facility.

\section{References}

1. Li, J.; Guo, D.; Wang, X.; Wang, H.; Jiang, H.; Chen, B. Nanoscale Res. Lett. 2010, 5, 1063-1071. doi:10.1007/s11671-010-9603-4

2. Benachour, H.; Bastogne, T.; Toussaint, M.; Chemli, Y.; Sève, A.; Frochot, C.; Lux, F.; Tillement, O.; Vanderesse, R.; Barberi-Heyob, M. PLoS One 2012, 7, e48617. doi:10.1371/journal.pone.0048617

3. Wang, C.; Cheng, L.; Liu, Z. Theranostics 2013, 3, 317-330. doi:10.7150/thno.5284

4. Matei, C.; Tampa, M.; Poteca, T.; Panea-Paunica, G.; Georgescu, S. R.; Ion, R. M.; Popescu, S. M.; Giurcaneanu, C. J. Med. Life 2013, 6, 50-54.

5. Tong, Z.-s.; Miao, P.-t.; Liu, T.-t.; Jia, Y.-s.; Liu, X.-d. Acta Pharmacol. Sin. 2012, 33, 1319-1324. doi:10.1038/aps.2012.45

6. Triesscheijn, M.; Baas, P.; Schellens, J. H. M.; Stewart, F. A. Oncologist 2006, 11, 1034-1044. doi:10.1634/theoncologist.11-9-1034

7. Nazir, S.; Hussain, T.; Ayub, A.; Rashid, U.; MacRobert, A. J. Nanomedicine 2014, 10, 19-34. doi:10.1016/j.nano.2013.07.001 
8. Bechet, D.; Couleaud, P.; Frochot, C.; Viriot, M. L.; Guillemin, F.; Barberi-Heyob, M. Trends Biotechnol. 2008, 26, 612-621. doi:10.1016/j.tibtech.2008.07.007

9. Moore, C. M.; Pendse, D.; Emberton, M. Nat. Clin. Pract. Urol. 2009, 6, 18-30. doi:10.1038/ncpuro1274

10. Hackenberg, S.; Scherzed, A.; Kessler, M.; Froelich, K.; Ginzkey, C.; Koehler, C.; Burghartz, M.; Hagen, R.; Kleinsasser, N. Int. J. Oncol. 2010, 37, 1583-1590.

11. Zhou, J.; Xu, N. S.; Wang, Z. L. Adv. Mater. 2006, 18, 2432-2435. doi:10.1002/adma.200600200

12. Premanathan, M.; Karthikeyan, K.; Jeyasubramanian, K.; Manivannan, G. Nanomedicine 2011, 7, 184-192. doi:10.1016/j.nano.2010.10.001

13. Raghupathi, K. R.; Koodali, R. T.; Manna, A. C. Langmuir 2011, 27, 4020-4028. doi:10.1021/la104825u

14. Singh, O. P.; Nehru, R. M. Asian J. Exp. Sci. 2008, 22, 45-50.

15. Tran, D. T.; Salmon, R. Australas. J. Dermatol. 2011, 52, 1-6. doi:10.1111/j.1440-0960.2010.00677.x

16. Rasmussen, J. W.; Martinez, E.; Louka, P.; Wingett, D. G. Expert Opin. Drug Delivery 2010, 7, 1063-1077. doi:10.1517/17425247.2010.502560

17. Moghimi, S. M.; Hunter, A. C.; Murray, J. C. FASEB J. 2005, 19 , 311-330. doi:10.1096/fj.04-2747rev

18. Wang, H.; Wingett, D.; Engelhard, M. H.; Feris, K.; Reddy, K. M.; Turner, P.; Layne, J.; Hanley, C.; Bell, J.; Tenne, D.; Wang, C.; Punnoose, A. J. Mater. Sci.: Mater. Med. 2009, 20, 11-22. doi:10.1007/s10856-008-3541-z

19. Buerki-Thurnherr, T.; Xiao, L.; Diener, L.; Arslan, O.; Hirsch, C.; Maeder-Althaus, X.; Grieder, K.; Wampfler, B.; Mathur, S.; Wick, P.; Krug, H. F. Nanotoxicology 2013, 7, 402-416. doi:10.3109/17435390.2012.666575

20. Ostrovsky, S.; Kazimirsky, G.; Gedanken, A.; Brodie, C. Nano Res. 2009, 2, 882-890. doi:10.1007/s12274-009-9089-5

21. Ahamed, M.; Akhtar, M. J.; Raja, M.; Ahmad, I.; Siddiqui, M. K. J.; AISalhi, M. S.; Alrokayan, S. A. Nanomedicine 2011, 7, 904-913. doi:10.1016/j.nano.2011.04.011

22. Akhtar, M. J.; Ahamed, M.; Kumar, S.; Khan, M. M.; Ahmad, J.; Alrokayan, S. A. Int. J. Nanomed. 2012, 7, 845-857. doi:10.2147/IJN.S29129

23. Hanley, C.; Layne, J.; Punnoose, A.; Reddy, K. M.; Coombs, I.; Coombs, A.; Feris, K.; Wingett, D. Nanotechnology 2008, 19, 295103. doi:10.1088/0957-4484/19/29/295103

24. Hu, Z.; Li, J.; Li, C.; Zhao, S.; Li, N.; Wang, Y.; Wei, F.; Chen, L.; Huang, Y. J. Mater. Chem. B 2013, 1, 5003-5013. doi:10.1039/C3TB20849D

25. Thurber, A.; Wingett, D. G.; Rasmussen, J. W.; Layne, J.; Johnson, L.; Tenne, D. A.; Zhang, J.; Hanna, C. B.; Punnoose, A. Nanotoxicology 2012, 6, 440-452. doi:10.3109/17435390.2011.587031

26. Yıldırım, Ö. A.; Unalan, H. E.; Durucan, C. J. Am. Ceram. Soc. 2013, 96, 766-773. doi:10.1111/jace.12218

27. Nghia, N. V.; Trung, T. N.; Truong, N. N. K.; Thuy, D. M. Open J. Synth. Theory Appl. 2012, 1, 18-22. doi:10.4236/ojsta.2012.12004

28. Xie, W.; Li, Y.; Sun, W.; Huang, J.; Xie, H.; Zhao, X. J. Photochem. Photobiol., A: Chem. 2010, 216, 149-155. doi:10.1016/j.jphotochem.2010.06.032

29. Gopinath, P.; Gogoi, S. K.; Chattopadhyay, A.; Ghosh, S. S. Nanotechnology 2008, 19, 075104. doi:10.1088/0957-4484/19/7/075104
30. Zeferino, R. S.; Flores, M. B.; Pal, U. J. Appl. Phys. 2011, 109, 014308. doi:10.1063/1.3530631

31. Ismail, A. F. M.; Ali, M. M.; Ismail, L. F. M. J. Photochem. Photobiol., B: Biol. 2014, 138, 99-108. doi:10.1016/j.jphotobiol.2014.04.006

32. Sharma, N.; Kumar, J.; Thakur, S.; Sharma, S.; Shrivastava, V. Drug Invent. Today 2013, 5, 50-54. doi:10.1016/j.dit.2013.03.007

33. Shah, A. H.; Manikandan, E.; Basheer, A. M.; Ganesan, V. J. Nanomed. Nanotechnol. 2013, 4, 1-6. doi:10.4172/2157-7439.1000168

34. Talari, M. K.; Abdul Majeed, A. B.; Tripathi, D. K.; Tripathy, M. Chem. Pharm. Bull. 2012, 60, 818-824.

35. Guo, D.; Bi, H.; Wang, D.; Wu, Q. Int. J. Biochem. Cell Biol. 2013, 45, 1849-1859. doi:10.1016/j.biocel.2013.06.002

36. Xia, T.; Kovochich, M.; Liong, M.; Mädler, L.; Gilbert, B.; Shi, H.; Yeh, J. I.; Zink, J. I.; Nel, A. E. ACS Nano 2008, 2, 2121-2134. doi: $10.1021 / \mathrm{nn} 800511 \mathrm{k}$

37. Wilhelmi, V.; Fischer, U.; Weighardt, H.; Schulze-Osthoff, K.; Nickel, C.; Stahlmecke, B.; Kuhlbusch, T. A. J.; Scherbart, A. M.; Esser, C.; Schins, R. P. F.; Albrecht, C. PLoS One 2013, 8, e65704. doi:10.1371/journal.pone.0065704

38. Hanley, C.; Thurber, A.; Hanna, C.; Punnoose, A.; Zhang, J.; Wingett, D. G. Nanoscale Res. Lett. 2009, 4, 1409-1420. doi:10.1007/s11671-009-9413-8

39. Robertson, C. A.; Evans, D. H.; Abrahamse, H. J. Photochem. Photobiol., B 2009, 96, 1-8. doi:10.1016/j.jphotobiol.2009.04.001

40. Mroz, P.; Yaroslavsky, A.; Kharkwal, G. B.; Hamblin, M. R. Cancers 2011, 3, 2516-2539. doi:10.3390/cancers3022516

41. James, S. A.; Feltis, B. N.; de Jonge, M. D.; Sridhar, M.; Kimpton, J. A.; Altissimo, M.; Mayo, S.; Zheng, C.; Hastings, A.; Howard, D. L.; Paterson, D. J.; Wright, P. F. A.; Moorhead, G. F.; Turney, T. W.; Fu, J. ACS Nano 2013, 7, 10621-10635. doi:10.1021/nn403118u

42. Shen, C.; James, S. A.; de Jonge, M. D.; Turney, T. W.; Wright, P. F. A.; Feltis, B. N. Toxicol. Sci. 2013, 136, 120-130. doi:10.1093/toxsci/kft187

43. Gandhi, V.; Ganesan, R.; Syedahamed, H. H. A.; Thaiyan, M. J. Phys. Chem. C 2014, 118, 9715-9725. doi:10.1021/jp411848

44. Skehan, P.; Storeng, R.; Scudiero, D.; Monks, A.; McMahon, J.; Vistica, D.; Warren, J. T.; Bokesch, H.; Kenney, S.; Boyd, M. R. J. Natl. Cancer Inst. 1990, 82, 1107-1112.

45. Mosmann, T. J. Immunol. Methods 1983, 65, 55-63. doi:10.1016/0022-1759(83)90303-4

46. Xiao, L.; Gu, L.; Howell, S. B.; Sailor, M. J. ACS Nano 2011, 5, 3651-3659. doi:10.1021/nn1035262

47. Redmond, R. W.; Gamlin, J. N. Photochem. Photobiol. 1999, 70 , 391-475. doi:10.1111/j.1751-1097.1999.tb08240.x

48. Ohkawa, H.; Ohishi, N.; Yagi, K. Anal. Biochem. 1979, 95, 351-358. doi:10.1016/0003-2697(79)90738-3 


\section{License and Terms}

This is an Open Access article under the terms of the Creative Commons Attribution License

(http://creativecommons.org/licenses/by/2.0), which permits unrestricted use, distribution, and reproduction in any medium, provided the original work is properly cited.

The license is subject to the Beilstein Journal of Nanotechnology terms and conditions:

(http://www.beilstein-journals.org/bjnano)

The definitive version of this article is the electronic one which can be found at:

doi:10.3762/bjnano.6.59 